\title{
HIV status disclosure among HIV-positive African and Afro-Caribbean people in the Netherlands
}

Citation for published version (APA):

Stutterheim, S. E., Shiripinda, I., Bos, A. E. R., Pryor, J. B., de Bruin, M., Nellen, J. F. J. B., Kok, G., Prins, J. M., \& Schaalma, H. P. (2011). HIV status disclosure among HIV-positive African and Afro-Caribbean people in the Netherlands. Aids Care-Psychological and Socio-Medical Aspects of Aids/Hiv, 23(2), 195205. https://doi.org/10.1080/09540121.2010.498873

Document status and date:

Published: 01/01/2011

DOI:

10.1080/09540121.2010.498873

Document Version:

Publisher's PDF, also known as Version of record

Document license:

Taverne

Please check the document version of this publication:

- A submitted manuscript is the version of the article upon submission and before peer-review. There can be important differences between the submitted version and the official published version of record.

People interested in the research are advised to contact the author for the final version of the publication, or visit the DOI to the publisher's website.

- The final author version and the galley proof are versions of the publication after peer review.

- The final published version features the final layout of the paper including the volume, issue and page numbers.

Link to publication

\footnotetext{
General rights Owners
rights.

- You may freely distribute the URL identifying the publication in the public portal. please follow below link for the End User Agreement:

www.umlib.nl/taverne-license

Take down policy

If you believe that this document breaches copyright please contact us at:

repository@maastrichtuniversity.nl

providing details and we will investigate your claim.
}

Copyright and moral rights for the publications made accessible in the public portal are retained by the authors and/or other copyright owners and it is a condition of accessing publications that users recognise and abide by the legal requirements associated with these

- Users may download and print one copy of any publication from the public portal for the purpose of private study or research.

- You may not further distribute the material or use it for any profit-making activity or commercial gain

If the publication is distributed under the terms of Article $25 \mathrm{fa}$ of the Dutch Copyright Act, indicated by the "Taverne" license above, 
AIDS Care

Psychological and Socio-medical Aspects of AIDS/HIV

ISSN: 0954-0121 (Print) 1360-0451 (Online) Journal homepage: https://www.tandfonline.com/loi/caic20

\section{HIV status disclosure among HIV-positive African and Afro-Caribbean people in the Netherlands}

Sarah E. Stutterheim , Iris Shiripinda, Arjan E.R. Bos , John B. Pryor , Marijn de Bruin , Jeannine F.J.B. Nellen, Gerjo Kok, Jan M. Prins \& Herman P. Schaalma

To cite this article: Sarah E. Stutterheim , Iris Shiripinda , Arjan E.R. Bos , John B. Pryor , Marijn de Bruin , Jeannine F.J.B. Nellen, Gerjo Kok, Jan M. Prins \& Herman P. Schaalma (2011) HIV status disclosure among HIV-positive African and Afro-Caribbean people in the Netherlands, AIDS Care, 23:2, 195-205, DOI: 10.1080/09540121.2010.498873

To link to this article: https://doi.org/10.1080/09540121.2010.498873

册 Published online: 22 Jan 2011.

Submit your article to this journal $\asymp$

LII Article views: 635

Q View related articles $\longleftarrow$

Citing articles: 6 View citing articles $ک$ 


\section{HIV status disclosure among HIV-positive African and Afro-Caribbean people in the Netherlands}

Sarah E. Stutterheim ${ }^{\mathrm{a} *}$, Iris Shiripinda ${ }^{\mathrm{b}}$, Arjan E.R. Bos ${ }^{\mathrm{a}}$, John B. Pryor ${ }^{\mathrm{c}}$, Marijn de Bruin ${ }^{\mathrm{d}}$, Jeannine F.J.B. Nellen ${ }^{\mathrm{e}}$, Gerjo Kok ${ }^{\mathrm{a}}$, Jan M. Prins ${ }^{\mathrm{e}}$ and Herman P. Schaalma ${ }^{\mathrm{a} \dagger}$

${ }^{a}$ Department of Work and Social Psychology, Faculty of Psychology and Neuroscience, Maastricht University, PO Box 616, 6200 MD, Maastricht, the Netherlands; ${ }^{b}$ STI AIDS the Netherlands, Amsterdam, the Netherlands; ${ }^{c}$ Department of Psychology, Illinois State University, Normal, IL, USA; ${ }^{d}$ Communication Science, Wageningen University, Wageningen, the Netherlands; ${ }^{e}$ Department of Internal Medicine, Division of Infectious Diseases, Tropical Medicine and AIDS, and Centre for Infection and Immunity Amsterdam (CINIMA), Academic Medical Centre, University of Amsterdam, Amsterdam, the Netherlands

(Received 12 January 2010; final version received 29 April 2010)

HIV status disclosure is often characterized as a dilemma. On the one hand, disclosure can promote health, social support, and psychological well-being. On the other, disclosure can lead to stigmatization, rejection, and other negative social interactions. Previous research has shown that HIV status disclosure is a reasoned process whereby the costs and benefits to oneself and to others are weighed. As such, understanding disclosure requires understanding the reasons for and against disclosure employed by people living with HIV (PLWH). In this study, disclosure among a population disproportionately affected by HIV in the Netherlands, namely African and Afro-Caribbean diaspora, was investigated. Reasons for nondisclosure were fear of stigmatization, previous negative experiences with disclosure, having observed the stigmatization of other PLWH, shame, the desire to protect others - particularly one's children and family - from stigmatization by association and/or worrying, and the belief that one's HIV status is a private matter. Participants reported disclosing because they were in a close and supportive relationship, disclosure led to emotional release, disclosure could lead to emotional or financial support, they felt a perceived duty to inform, and they had a desire to educate others about sexual risktaking. The findings suggest that stigma plays an important role in disclosure decisions among these populations. They further point to a need for HIV-related stigma reduction interventions in African and Afro-Caribbean communities and culturally sensitive counseling for PLWH whereby caregivers do not automatically assume that disclosure is best but rather provide a safe environment in which the costs and benefits of disclosure can be weighed and strategies for disclosure can be developed, if perceived as beneficial by PLWH.

Keywords: HIV/AIDS; disclosure; stigma; ethnic minorities; culture

\section{Introduction}

In the Netherlands, ethnic minorities are disproportionately affected by HIV/AIDS. In fact, among people living with HIV (PLWH) in the Netherlands, one in every five is of African or Caribbean origin (HIV Monitoring Foundation, 2008). Previous research has demonstrated that, because of HIV-related stigma, disclosure of HIV status is an important concern among PLWH of African and Caribbean origin, both in their home countries and among the diaspora (Anderson \& Doyal, 2004; Kumar, Waterman, Kumari, \& Carter, 2006; Visser, Neufeld, de Villiers, Forsyth, \& Makin, 2008).

The term stigma refers to a distinctive, discrediting characteristic that renders its bearer tainted, flawed, or inferior in the eyes of others (Bos, Kok,
\& Dijker, 2001; Crocker, Major, \& Steele, 1998; Goffman, 1963; Jones et al., 1984). The origin of stigmatization lies in the cognitive representations of people who possess the stigmatized condition. These cognitive representations may trigger emotional and behavioral reactions from others that subsequently result in stigmatizing behavior such as avoidance, blaming, and exclusion (Bos, Schaalma, \& Pryor, 2008; Dijker \& Koomen, 2003; Stutterheim et al., 2009). Stigmatizing responses to PLWH are promoted by a number of perceptions including the perception that HIV is highly contagious, the perception that HIV is severe and fatal, and the perception that PLWH are personally responsible for having acquired HIV. HIV-related stigmatization is further exacerbated by the fact that HIV has traditionally been associated with certain forms of norm-violating

\footnotetext{
*Corresponding author. Email: s.stutterheim@maastrichtuniversity.nl

†Professor Herman P. Schaalma passed away unexpectedly on 25 July 2009.
} 
behavior such as homosexuality, commercial sex work, and intravenous drug use (Bos, Dijker, \& Koomen, 2007; Herek, 1999).

Because of HIV-related stigma, PLWH face a dilemma of disclosure (Pachankis, 2007). On the one hand, disclosure can lead to stigmatization in the form of discrimination, rejection, and other negative social interactions (Black \& Miles, 2002; Landau \& York, 2004), and stigmatization has been found to be detrimental to PLWH's psychological well-being (Riggs, Vosvick, \& Stallings, 2007; Stutterheim et al., 2009; Vanable, Carey, Blair, \& Littlewood, 2006). On the other, disclosure can be beneficial. It has been found to promote treatment adherence (Chesney \& Smith, 1999), safe sex (Melchert \& Patterson, 1999; Serovich \& Mosack, 2003), social support provision (Bos, Kanner, Muris, Janssen, \& Mayer, 2009; Smith, Rossetto, \& Peterson, 2008), closeness in relationships (Herek \& Capitanio, 1996; Parsons, VanOra, Missildine, Purcell, \& Gomez, 2004), and psychological well-being (Derlega, Winstead, Oldfield, \& Barbee, 2003; Smart \& Wegner, 1999). Clearly, both advantages and disadvantages of disclosure have been established.

So what determines whether one discloses or conceals one's HIV status? Previous research has contended that HIV status disclosure is a reasoned process whereby the perceived costs and benefits to oneself and to others are weighed. When PLWH consider the benefits to outweigh the costs, disclosure is highly probable. When the costs outweigh the benefits, concealment is more likely (Black \& Miles, 2002; Derlega, Winstead, Greene, Serovich, \& Elwood, 2004; Serovich, 2001; Valle \& Levy, 2009). As such, understanding disclosure patterns requires understanding PLWH's reasons for and against disclosure (Calin, Green, Hetherton, \& Brook, 2007). This has been studied extensively in North America and Europe but less extensively in Africa or the Caribbean (for an overview of the literature, see Table 1). Almost no studies exploring the reasons for and against disclosure among HIV-positive African or Caribbean diaspora have been conducted. One exception is a study conducted by Calin and colleagues (2007) who investigated disclosure among Black African PLWH in the UK. In their study, reasons for nondisclosure cited were fear of rejection, broken confidentiality, assumptions of promiscuity by family and friends, negative previous experiences with disclosure, and the desire to protect others, particularly family members, from worrying. Reasons for disclosure included knowing that one's current or previous sexual partner was at risk for infection, believing that one's partner had a right to know, and knowing that one's confidant is also HIV positive. Participants also reported disclosing their status because they were in a close relationship with someone they could trust, because confiding brought relief, because disclosure could lead to emotional support, and because they felt the need to explain physical decline (Calin et al., 2007).

Given the high prevalence of HIV among African and Afro-Caribbean diaspora, we believe that additional investigation of the reasons for and against disclosure employed by these PLWH is warranted, especially given that, to date, only one study has explored disclosure among African diaspora and no studies have investigated disclosure among AfroCaribbean diaspora. Further, we contend that a better understanding of how HIV-positive African and Afro-Caribbean diaspora approach the issue of disclosure will enable professionals to better support these PLWH. Consequently, in this study, we explored the reasons for nondisclosure and disclosure employed by African, Dutch Antillean, and Surinamese immigrants living in the Netherlands.

\section{Methods}

Study participants were recruited in one of three ways: directly by the interviewers (snowball sampling), via an online recruitment announcement placed on the Dutch HIV Association website, or through folders distributed by the Humanitas Foundation and/or HIV nurses working in Dutch hospitals. Once recruited, participants were provided with information regarding the purpose of the study and the procedure by either a researcher or an interviewer. Informed consent was obtained and a monetary reward of $€ 30$ was provided. Approval for this study was granted by the Faculty of Psychology and Neuroscience's Ethics Committee at Maastricht University.

In total, 42 PLWH of African $(n=15)$, Dutch Antillean $(n=11)$, or Surinamese $(n=17)$ descent (one participant identified himself as both Antillean and Surinamese) were interviewed in face-to-face semistructured interviews by trained peer interviewers or researchers (SS, IS, or MB) in either Dutch or English, depending on the participant's preference. Interviews were conducted between January 2005 and May 2008. A structured protocol of theory-based open-ended questions with follow-up probes was employed in the interviews. Sociodemographic data were also collected and are displayed in Table 2. Interviewers were not aware of participants' disclosure status prior to the interview. This was considered advantageous as previous knowledge of disclosure status could generate interviewer bias and impact the direction of the conversation. All interviews were 
Table 1. Overview of the literature on reasons for and against disclosure of HIV status.

Author(s), year, and study sample

\section{Reasons for disclosure \\ Being in a close and supportive relationship}

Emotional catharsis

Disclosure could lead to emotional support

Disclosure could lead to instrumental/ practical support

Disclosure could lead to financial/ instrumental support

Perceived duty to inform

Desire to educate regarding sexual risk-taking

To explain physical decline

\section{Reasons for nondisclosure}

Fears stigmatization/discrimination/ negative reactions

Specifically...

Rejection/abandonment

Being blamed for HIV infection

Gossip/breaches of confidentiality

\section{Abuse}

Previous disclosures have led to stigmatization
Calin, Green, Hetherton, \& Brook, 2007 (Africans in UK); Derlega, Winstead, Greene, Serovich, \& Elwood, 2004 (USA); Gorbach et al., 2004 (MSM USA); Sachperoglou \& Bor, 2001 (Greece); Simoni et al., 1995 (Women USA); Visser, Neufeld, de Villiers, Forsyth, \& Makin, 2008 (Women South Africa)

Calin et al., 2007 (Africans in UK); Derlega et al., 2004 (USA); Ostrom, Serovich, Lim, \& Mason, 2006 (Women USA); Serovich, 2001 (MSM USA); Serovich \& Mosack, 2003 (MSM USA); Valle \& Levy, 2009 (African-American IDU USA) Black \& Miles, 2002 (African-American women USA); Calin et al., 2007 (Africans in UK); Chandra, Deepthivarma, \& Manjula, 2003 (India); Derlega et al., 2004 (USA); Ford, Wirawan, Sumantera, Sawitri, \& Stahre, 2004 (Indonesia); Greeff et al., 2008 (Sub-Saharan Africa); Ostrom et al., 2006 (Women USA); Serovich, 2001 (MSM USA); Simoni et al., 1995 (Women USA); Valle \& Levy, 2009 (African-American IDU USA); Yoshioka \& Schustack, 2001 (Asian-Americans USA)

Greeff et al., 2008 (Sub-Saharan Africa); Ostrom et al., 2006 (Women USA);

Chandra et al., 2003 (India); Valle \& Levy, 2009 (African-American IDU USA)

Calin et al., 2007 (Africans in UK); Chandra et al., 2003 (India); Derlega et al., 2004 (USA); Gorbach et al., 2004 (MSM USA); Holt et al., 1998 (UK); Ostrom et al., 2006 (Women USA); Parsons, VanOra, Missildine, Purcell, \& Gomez, 2004 (IDU USA); Petrak, Doyle, Smith, Skinner, \& Hedge, 2001 (UK); Serovich, 2001 (MSM USA); Serovich \& Mosack, 2003 (MSM USA); Siegel, Lekas, \& Schrimshaw, 2005 (Women USA); Simoni et al., 1995 (Women USA); Sowell, Seals, Phillips, \& Julious, 2003 (Women USA); Visser et al., 2008 (Women South Africa)

Black \& Miles, 2002 (African-American women USA); Derlega et al., 2004 (USA); Frye et al., 2009 (IDU USA); Greeff et al., 2008 (Sub-Saharan Africa); Paxton, 2002 (Africa and Pacific Asia); Petrak et al., 2001 (UK); Serovich \& Mosack, 2003 (MSM USA); Visser et al., 2008 (Women South Africa)

Calin et al., 2007 (Africans in UK); Greeff et al., 2008 (Sub-Saharan Africa); Visser et al., 2008 (Women South Africa)

Chandra et al., 2003 (India); Holt et al., 1998 (UK); Kumar, Waterman, Kumari, \& Carter, 2006 (Women Barbados); Parsons et al., 2004 (IDU USA); Petrak et al., 2001 (UK); Schrimshaw \& Siegel, 2003 (USA); Steward et al., 2008 (India); Valle \& Levy, 2009 (African-American IDU USA)

Calin et al., 2007 (Africans in UK); Derlega et al., 2004 (USA); Ford et al., 2004 (Indonesia); Frye et al., 2009 (IDU USA); Gorbach et al., 2004 (MSM USA); Greeff et al., 2008 (Sub-Saharan Africa); Levy et al., 1999 (France); Serovich, 2001 (MSM USA); Serovich \& Mosack, 2003 (MSM USA); Siegel et al., 2005 (Women USA); Simoni et al., 1995 (Women USA); Valle \& Levy, 2009 (African-American IDU USA); Visser et al., 2008 (Women South Africa); Zea, Reisen, Poppen, Bianchi, \& Echeverry, 2003 (Latino MSM USA)

Calin et al., 2007 (Africans in UK); Greeff et al., 2008 (Sub-Saharan Africa); Serovich, 2001 (MSM USA); Valle \& Levy, 2009 (African-American IDU USA); Visser et al., 2008 (Women South Africa)

Calin et al., 2007 (Africans in UK); Greeff et al., 2008 (Sub-Saharan Africa); Petrak et al., 2001 (UK); Serovich \& Mosack, 2003 (MSM USA); Siegel et al., 2005 (Women USA)

Ford et al., 2004 (Indonesia); Valle \& Levy, 2009 (African-American IDU USA); Visser et al., 2008 (Women South Africa)

Black \& Miles, 2002 (African-American women USA); Calin et al., 2007 (Africans in UK); Greeff et al., 2008 (Sub-Saharan Africa) 
Table 1 (Continued)

Author(s), year, and study sample

Has observed stigmatization of other PLWH

Feels shame

Wants to protect others from courtesy stigma

Wants to protect others from worrying

HIV status is a private matter

Disclosure is futile

The relationship is superficial

Communication difficulties
Black \& Miles, 2002 (African-American women USA); Frye et al., 2009 (IDU USA)

Black \& Miles, 2002 (African-American women USA); Derlega et al., 2004 (USA); Serovich \& Mosack, 2003 (MSM USA); Simoni et al., 1995 (Women USA) Black \& Miles, 2002 (African-American women USA); Chandra et al., 2003 (India); Greeff et al., 2008 (Sub-Saharan Africa); Ostrom et al., 2006 (Women USA); Yoshioka \& Schustack, 2001 (Asian-Americans USA)

Black \& Miles, 2002 (African-American women USA); Calin et al., 2007 (Africans in UK); Derlega et al., 2004 (USA); Ostrom et al., 2006 (Women USA); Petrak et al., 2001 (UK); Serovich, 2001 (MSM USA); Simoni et al., 1995 (Women USA); Valle \& Levy, 2009 (African-American IDU USA); Vallerand, Hough, Pittiglio, \& Marvicsin, 2005 (Women USA); Waugh, 2003 (UK)

Derlega et al., 2004 (USA); Gorbach et al., 2004 (MSM USA); Ostrom et al., 2006 (Women USA); Schrimshaw \& Siegel, 2003 (USA); Serovich \& Mosack, 2003 (MSM USA); Siegel et al., 2005 (Women USA); Valle \& Levy, 2009 (AfricanAmerican IDU USA)

Chandra et al., 2003 (India)

Derlega et al., 2004 (USA); Serovich \& Mosack, 2003 (MSM USA); Visser et al., 2008 (Women South Africa)

Derlega et al., 2004 (USA); Schrimshaw \& Siegel, 2003 (USA); Serovich \& Mosack, 2003 (MSM USA); Visser et al., 2008 (Women South Africa) recorded with a digital voice recorder and transcribed verbatim.

Data were processed using QSR NVivo 2.0. Each transcript was read thoroughly while listening to the corresponding recording to identify emerging themes and establish categories to which text fragments were assigned. As coding occurred, categories and subcategories were linked to one another. All emergent categories were documented, as were changes made to the categories and the rationale for the changes made. Coding continued until saturation was evident and no new codes were formed. Following the within-case analyses of the individual transcripts, across-case analyses were conducted to identify the overarching themes relevant to the different ethnic groups and the sample as a whole.

\section{Results}

\section{Disclosure targets}

Participants reported a number of disclosure targets including immediate family, extended family, sexual or romantic partners, friends, and colleagues or management at work. Although the qualitative methods and approach employed in this study were not designed to establish estimates of disclosure prevalence, the data did suggest that partners and immediate family members are the most common targets for disclosure, followed by friends and extended family. Disclosure at work was infrequent.

\section{Reasons for nondisclosure}

Perhaps the most prevalent reason reported for concealing one's HIV status was fear of stigmatization. In fact, many participants indicated that, in the past, they had personally experienced stigmatization following the disclosure of their HIV status and did not want to experience these kinds of reactions again. One Surinamese woman stated, "I have had a couple of bad experiences and I don't want that again." Another Rwandan woman said, "I did not want to go down that road again." Also, a number of men who have sex with men (MSM) referred to poor experiences related to coming out about their sexual orientation and stated that they expected similar reactions to an HIV status disclosure: The following comments of a Surinamese MSM illustrate this:

\footnotetext{
Participant: I have seen how people reacted to my homosexuality and I thought, "Wow!"

Interviewer: Was it very negative?

Participant: From some colleagues, it was, but it wasn't directed straight at me. I just heard how they talked about it after the fact. One guy told another and that guy told another. I just think, "Wow, if they talk about gays that way, what would they say about HIV?"' So I just decided I'd rather not have that.
}

Additionally, a number of participants indicated that they would rather keep their status concealed after seeing how other PLWH are stigmatized. One Antillean man stated, "Now they don't know about me but I have heard how they talk about other people 
Table 2. Demographic and background characteristics of sample $(n=42)$.

\begin{tabular}{|c|c|c|c|}
\hline Variable & African $(n=15 ; \%)$ & Antillean $(n=11 ; \%)$ & Surinamese $(n=17 ; \%)$ \\
\hline \multicolumn{4}{|l|}{ Gender } \\
\hline Male & 43.7 & 70.0 & 47.1 \\
\hline Female & 56.3 & 30.0 & 52.9 \\
\hline \multicolumn{4}{|l|}{ Age } \\
\hline Years of age, mean (SD) & $35.6(8.5)$ & $43.8(10.2)$ & $37.8(11.8)$ \\
\hline Range (min-max) & $18-51$ & $27-62$ & $22-70$ \\
\hline \multicolumn{4}{|l|}{ Level of education ${ }^{a}$} \\
\hline Low & 18.8 & 30.0 & 23.5 \\
\hline Moderate & 50.0 & 30.0 & 53.0 \\
\hline High & 31.2 & 40.0 & 23.5 \\
\hline \multicolumn{4}{|l|}{ Employment/income } \\
\hline Full-time work & 18.8 & 33.4 & 25.0 \\
\hline Part-time work & 12.5 & 22.2 & 0.0 \\
\hline Receiving benefits & 43.8 & 22.2 & 58.4 \\
\hline Studying & 6.2 & 0.0 & 8.3 \\
\hline Volunteer work & 6.2 & 0.0 & 0.0 \\
\hline Combination & 12.5 & 22.2 & 8.3 \\
\hline \multicolumn{4}{|l|}{ Marital status } \\
\hline Married & 20.0 & 0.0 & 13.3 \\
\hline Common law & 13.3 & 0.0 & 13.3 \\
\hline Single & 53.4 & 90.0 & 53.3 \\
\hline Divorced & 0.0 & 0.0 & 13.3 \\
\hline Widowed & 13.3 & 10.0 & 6.8 \\
\hline \multicolumn{4}{|l|}{ Sexual orientation } \\
\hline Heterosexual & 80.0 & 40.0 & 68.8 \\
\hline Homosexual & 20.0 & 60.0 & 31.2 \\
\hline \multicolumn{4}{|l|}{ Means of transmission } \\
\hline Through sex & 81.3 & 100.0 & 93.8 \\
\hline Through blood transfusion & 12.5 & 0.0 & 6.2 \\
\hline Other & 6.2 & 0.0 & 0.0 \\
\hline \multicolumn{4}{|l|}{ Time since diagnosis } \\
\hline Less than 2 years & 20.0 & 0.0 & 13.3 \\
\hline $2-4$ years & 20.0 & 20.0 & 13.3 \\
\hline 4-6 years & 20.0 & 30.0 & 20.0 \\
\hline $6-8$ years & 0.0 & 0.0 & 33.4 \\
\hline $8-10$ years & 20.0 & 30.0 & 0.0 \\
\hline More than 10 years & 20.0 & 20.0 & 20.0 \\
\hline \multicolumn{4}{|l|}{ Treatment } \\
\hline Antiretroviral therapy & 60.0 & 85.7 & 100.0 \\
\hline No therapy & 40.0 & 14.3 & 0.0 \\
\hline \multicolumn{4}{|l|}{ Current health } \\
\hline Very poor & 6.7 & 0.0 & 11.1 \\
\hline Poor & 13.3 & 0.0 & 0.0 \\
\hline Reasonable & 6.7 & 14.3 & 33.3 \\
\hline Good & 26.7 & 42.8 & 44.5 \\
\hline Very good & 33.3 & 14.3 & 0.0 \\
\hline Excellent & 13.3 & 28.6 & 11.1 \\
\hline
\end{tabular}

${ }^{a}$ Low, less than highschool; moderate, highschool and some vocational training; and high, college or university degree.

Note: Percentage of those participants with valid data; in most cases, missing data did not exceed $10 \%$; on some sensitive topics such as means of transmission, treatment, and current health, missing data exceeded $10 \%$. 
who have HIV, like 'Have you seen him?'. I'd rather not go through that."

In fact, the PLWH in our study were keenly aware of the potential stigmatizing reactions they may experience if they choose to disclose. Some participants mentioned thinking that others will reject, avoid, or abandon them. A Ugandan woman stated, "If I come and tell you, you'll just throw me out. I keep quiet." An Antillean man further illustrated this: "I don't dare talk about my HIV because I am scared to be rejected." Another form of stigmatization feared was gossip and breaches of confidentiality. Gossip was a major concern given the fact that the diaspora communities in the Netherlands are relatively small and that members are well-connected. The following excerpt from an interview with a young Zambian woman illustrates this fear of gossip:

You can't trust people! Definitely don't tell other people 'cause if she tells another - one person "don't talk", [that person] will go and tell another one, and they will go to another one [saying,] "Don't you say it but that one is positive."

Some participants also claimed that disclosure would lead to blaming. One Surinamese man said, "I know exactly how they think in those circles, and I don't feel like being confronted with this whole thing like that maybe it's because of my 'sins'. I don't want a whole sermon on it." This fear of blaming appeared to be particularly salient among participants with religious families, perhaps reflecting how the prominence of the Christian faith in these diaspora communities impacts PLWH's sense of acceptance by others, of rather, lack thereof.

Another reason cited for nondisclosure was shame. When asked why she has not told people that she is HIV positive, one woman from Cameroon answered, "Because of the shame it carries, the disgrace it carries." Another male participant from Suriname said, "I'm ashamed of it. I am ashamed that I have HIV. I don't tell people. Those who know, know. I am just so ashamed of it." This reflects what is termed internalized stigma. Internalized stigma occurs when a person possessing the stigmatized condition internalizes society's negative views about that condition (Lee, Kochman, \& Sikkema, 2002).

Yet another reason for nondisclosure related to the impact disclosure could have on others. Many participants reported not wanting to disclose because it may result in stigmatization by association toward, particularly, their children. Stigmatization by association, also termed courtesy stigma, is a phenomenon whereby the negative attitudes toward a stigmatized person are extended to people associated with that person (Goffman, 1963; Neuberg, Smith,
Hoffman, \& Russell, 1994). One African participant said she would not tell others, "especially for my son. They will point at him and I don't want that." Another woman from the Dutch Antilles said, "Your kids suffer. Everyone will tell the other kids and then my kids won't have friends anymore. No, leave that problem to me. Let me experience it all, not my kids. I want them to have a good childhood." Again, concerns regarding the potential for stigmatization by association appeared to be particularly relevant given the small and well-connected nature of the diaspora communities.

Also, many participants conveyed opting to conceal their status so as to spare others, particularly their parents and children, from pain and from being worried. One Antillean man said, "I have told a few of my closest friends but not my parents because I think it might be too much for them." Another Kenyan man described his decision to not tell his parents as follows:

Well, when I knew that I was doing good, I thought it is not really a good idea to tell my parents because it might give them stress, especially when you are the one that's prayed for. You will worry them so I thought it is good I keep it like that [quiet].

Another participant, originally from Suriname, conveyed that she did not want to tell her children because of "the grief it would bring them, that they would not be able to go on with their lives, that they would be too concerned, and that they would think, 'mom is going to die soon.'"

A final reason provided for nondisclosure was the right to privacy. A number of participants indicated that they felt no need or obligation to share their status while they are still healthy and able to function. One Ugandan man stated, "I don't see any reason to tell them yet that this is the situation. I don't tell them when I have a headache or stub my toe, cross the street, etc. Likewise, I don't feel it is valuable to tell."

\section{Reasons for disclosure}

Participants also conveyed a number of reasons in favor of disclosure. The first has to do with the nature of the relationship between the PLWH and the person to whom they disclosed. Participants who felt they were in a close, trusting relationship also felt that disclosure to that person was appropriate. One Kenyan man stated, "I tell them - the ones that I trust. You can't say it to anybody but you have some people sometimes you trust." Another Antillean man said, "I told people I could trust - people I have a connection with." Yet another participant from Suriname, when asked why he told particular 
people, responded, "Because I have a good relationship with them."

Another reason for disclosure was emotional catharsis. A number of participants reported no longer wanting to keep their "secret" to themselves. One Antillean man said, "When I kept it to myself, I didn't feel good. I didn't feel good because I was keeping this secret and it just makes you depressed." Another man, who is both Surinamese and Antillean, said, "It was too much. You just feel caged and then you need to vent so you make a choice: 'I'm going to tell it now." Also, a Zambian woman indicated that she had told her sister because "it was so terrible to me so I can't hold it."

An additional reason for disclosure was the need for social, instrumental, and/or financial support. One Surinamese participant stated, "I felt that they needed to know because it is a difficult thing. I don't know how to say it... I just thought they needed to know so that they know what I am dealing with." Another woman from Zimbabwe reported having told some family members in order to ensure support for her children:

What if something happens to me now? Who would look after my kids? Then you start thinking of your relatives and say, "I think this person could really take care of my kids," and then, in that way, you really confide in them and then you tell them.

Yet another reason for disclosure provided was that the PLWH felt a sense of responsibility or duty to inform new sexual partners. Many participants reported feeling compelled to share their status with new sexual partners. One Antillean participant said, "I tell it right away and they can decide if they want to get involved with me." This sense of responsibility and duty is also exemplified by the following comment from an African woman:

I have a new boyfriend. We have talked and I am working on telling him. He wants a relationship with me and wants us to be honest. He's told me a few things about himself and I should tell him.

The final noteworthy justification for HIV status disclosure was the desire to educate others. A number of participants reported that they would be willing to be open about their HIV status if it would contribute to decreasing others' sexual risk-taking. One young Surinamese woman said, "I know that she [a friend] is kind of easy with the boys and stuff so I told her because it is not something you expect. You don't think you can get HIV." Another Antillean participant said, "If I know that you will do something with the information, I'll tell you."

\section{Discussion}

Although previous studies have established a number of reasons for and against disclosure employed by PLWH in Western countries and, to some extent, the developing world (see Table 1), this study is, to our knowledge, one of the first to explore how HIVpositive African and Afro-Caribbean diaspora approach decisions to disclose. In our study, the reasons for nondisclosure reported were fear of stigmatization, previous negative experiences with disclosure, having observed the stigmatization of other PLWH, shame, the desire to protect others - particularly one's children and family - from stigmatization by association and/or worrying, and the belief that one's HIV status is a private matter. Participants reported disclosing because they were in a close and supportive relationship, disclosure led to emotional release, disclosure could lead to emotional or financial support, they felt a perceived duty to inform, and they had a desire to educate others about sexual risktaking. These results are very much in line with the work of Calin and colleagues (2007) who studied disclosure among Black African PLWH in the UK.

Our findings, as well as those of Calin et al. (2007), suggest that stigma plays an important role in disclosure decisions among African and AfroCaribbean diaspora. In our study, participants not only cited fear of direct stigmatization and stigmatization by association as reasons for nondisclosure; but they also reported personal experiences with enacted stigma, shame (i.e., internalized stigma), and the stigmatization of other PLWH as justifications for HIV status concealment. This is not surprising given that high levels of stigma have been reported in African and Caribbean countries (Anderson et al., 2008; Kalichman \& Simbayi, 2004). In a study conducted with PLWH in Sub-Saharan Africa, Greeff and colleagues (2008) found that refusal to disclose was a result of seeing how other PLWH had been treated. Also, participants cited the effect disclosure could have on the family (i.e., being shunned and stigmatized) as a reason for concealment. In a study conducted in Barbados, $30 \%$ of participants that had only disclosed their HIV status to health-care providers indicated fear of stigmatization as the reason for nondisclosure to others. An additional $23 \%$ indicated not disclosing to their current sex partner in order to avoid abnormal reactions and possible violence (Kumar et al., 2006). Clearly, our findings with African and Afro-Caribbean diaspora in the Netherlands are congruent with research results from studies conducted in Africa and the Caribbean. 
Previous research has contended that cultural values may play an important role in disclosurerelated decision-making (Simoni et al., 1995; Yoshioka \& Schustack, 2001). Interestingly, our analyses did not lead us to believe that the reasons employed by African and Afro-Caribbean diaspora in the Netherlands differed substantially from those employed by North American and European PLWH or by PLWH in other parts of the world. In fact, many of the reasons for and against disclosure cited by the participants in our study have also been found in studies conducted not only in the countries from which our participants originated but also elsewhere (for an overview of the literature, see Table 1). Perhaps it is not the case that cultural values generate different reasons for and against disclosure but rather that cultural values impact the importance assigned to a given reason. It may be that in some cultures some reasons weigh more heavily than others. For example, among Asian PLWH, fear of bringing shame to the family and thus the desire to protect family for stigmatization by association may weigh heavier than other reasons (Yoshioka \& Schustack, 2001). Among African PLWH, who have likely been subjected to or observed more stigmatization than many other PLWH, fear of stigmatization may weigh heavier than other reasons (Greeff et al., 2008). In our study, we found that fears of gossip and stigmatization by association were particularly salient reasons for nondisclosure because of the relatively small and well-connected nature of diaspora communities. We recommend that future research follow this qualitative study with quantitative investigations of, firstly, the relative importance of each of the reasons for and against HIV status disclosure across communities and cultures and, secondly, the impact of the relative weighting of reasons on actual disclosure.

Some limitations to this study should be mentioned. First, given the qualitative nature of the data, caution should be applied in generalizing the results of this study to other populations. Second, despite efforts to interview a relatively equal number of men and women per group and to have representative participants in terms of educational attainment, age, and sexual orientation, in this study, Antillean women and older Africans were underrepresented while highly educated Antilleans and gay Antillean men were overrepresented. Nonetheless, the reasons cited in this study appeared relatively consistent across all participants thus suggesting that these themes cut across the boundaries of gender, age, education, and sexual orientation. Third, there is potential for interviewer bias in this study. This, however, was combated insofar as possible by the use of digital voice recordings and verbatim transcriptions (Hancock, 1998).

Our finding that stigmatization impedes HIV status disclosure has important practical implications. Firstly, it points to the need for culturally sensitive counseling for PLWH of African and AfroCaribbean descent. We contend that, given the high prevalence of stigma in African and Caribbean communities (Anderson et al., 2008; Kalichman \& Simbayi, 2004), health-care providers should not automatically assume that disclosure of HIV status is best. Rather, they should consider the cultural context in which disclosure occurs and the potential for negative reactions to HIV status disclosure. In their efforts to support African and Afro-Caribbean PLWH, we recommend that health-care providers use their unique role to provide these PLWH with a safe environment in which the costs and benefits of disclosure can be weighed and strategies for effective disclosure can be developed, if perceived as beneficial by PLWH. A supportive and safe environment for PLWH is imperative (Bos, Schaalma, \& Pryor, 2008; Nyblade, Pande, Mathur, MacQuarrie, \& Kidd, 2003) and can be promoted not only in health-care providers' offices but also in the communities in which HIV-related stigma is so prevalent. We recommend culturally appropriate theory and evidencebased HIV-related stigma reduction interventions that tackle a number of manifestations of stigma across a broad range of settings within and beyond African and Afro-Caribbean communities (see Bos, Schaalma, \& Pryor, 2008; Brown, Macintyre, \& Trujillo, 2003; Stutterheim et al., 2009). Also, given that some participants conveyed negative experiences with disclosure in the past, we recommend the implementation of skill-building interventions that aid and support PLWH to disclose in ways that are most advantageous and least likely to generate negative responses (see Bos, Dijker, \& Koomen, 2007). Further, structural supports for PLWH (e.g., ongoing counseling programs, support groups) can also contribute to more advantageous disclosures of HIV status and ameliorate the negative impact of HIV-related stigma experiences.

\section{Acknowledgements}

The authors thank the interview participants for sharing their stories and the Dutch AIDS Fonds and Abbott for their financial contribution (grant numbers 2006092 and 7004). They also thank the interviewers (Chantal Rumanzi, Emmy Markelo, Erik Beune, Juan Walter, Mikel Haman, Mirte Wibaut, Rubelto Baker, and Urmy Macnack), the PLUS project and HIV Stigma and Taboo project committees (Nicole van Kesteren at TNO; Ronald Brands and Maartje Liebregts at the Dutch HIV 
Association; Mariette Hamers, Evert van Veen, and Onno de Zwart at the Community Health Services in Rotterdam; Stephan Cremer and Juan Walter at the Community Health Services in Amsterdam; and Fetzen de Groot at the Community Health Services in Groningen), and the students who transcribed the interviews (Anne van Middelaar, Carolien van Wagenberg, Danielle Pool, Joyce van Leendert, Roy van Veldhuizen, Sanne van Lieshout, and Simone Heijnen). Thank you also to the Dutch HIV Association, Humanitas and the Professional Organization of HIV Consultants for their efforts in recruiting participants, and to two anonymous reviewers whose comments improved the quality of this paper.

\section{References}

Anderson, J., \& Doyal, L. (2004). Women from Africa living with HIV in London: A descriptive study. AIDS Care, 16(1), 95-105.

Anderson, M., Elam, G., Gerver, S., Solarin, I., Fenton, K., \& Easterbrook, P. (2008). HIV/AIDS-related stigma and discrimination: Accounts of HIV-positive Caribbean people in the United Kingdom. Social Science and Medicine, 67(5), 790-798.

Black, B.P., \& Miles, M.S. (2002). Calculating the risks and benefits of disclosure in African American women who have HIV. Journal of Obstetric, Gynecologic \& Neonatal Nursing, 31(6), 688-697.

Bos, A.E.R., Dijker, A.J.M., \& Koomen, W. (2007). Sex differences in emotional and behavioral responses to $\mathrm{HIV}+$ individuals' expression of distress. Psychology \& Health, 22(4), 493-511.

Bos, A.E.R., Kanner, D., Muris, P., Janssen, B., \& Mayer, B. (2009). Mental illness stigma and disclosure: Consequences of coming out of the closet. Issues in Mental Health Nursing, 30(8), 509-513.

Bos, A.E.R., Kok, G., \& Dijker, A.J. (2001). Public reactions to people with HIV/AIDS in the Netherlands. AIDS Education and Prevention, 13(3), 219-228.

Bos, A.E.R., Schaalma, H.P., \& Pryor, J.B. (2008). Reducing AIDS-related stigma in developing countries: The importance of theory- and evidence-based interventions. Psychology, Health \& Medicine, 13(4), 450-460.

Brown, L., Macintyre, K., \& Trujillo, L. (2003). Interventions to reduce HIV/AIDS stigma: What have we learned? AIDS Education and Prevention, 15(1), 49-69.

Calin, T., Green, J., Hetherton, J., \& Brook, G. (2007). Disclosure of HIV among black African men and women attending a London HIV clinic. AIDS Care, 19(3), 385-391.

Chandra, P.S., Deepthivarma, S., \& Manjula, V. (2003). Disclosure of HIV infection in south India: Patterns, reasons and reactions. AIDS Care, 15(2), 207-215.

Chesney, M.A., \& Smith, A.W. (1999). Critical delays in HIV testing and care: The potential role of stigma. American Behavioral Scientist, 42(7), 1162-1174.

Crocker, J., Major, B., \& Steele, C. (1998). Social stigma. In D.T. Gilbert, S.T. Fiske, \& G. Lindzey (Eds.), The handbook of social psychology (4th ed., Vols. 1 \& 2, pp. 504-553). New York, NY: McGraw-Hill.

Derlega, V.J., Winstead, B.A., Greene, K., Serovich, J., \& Elwood, W.N. (2004). Reasons for HIV disclosure/ nondisclosure in close relationships: Testing a model of HIV-disclosure decision making. Journal of Social and Clinical Psychology, 23(6), 747-767.

Derlega, V.J., Winstead, B.A., Oldfield, E.C., III, \& Barbee, A.P. (2003). Close relationships and social support in coping with HIV: A test of sensitive interaction systems theory. AIDS and Behavior, 7(2), 119-129.

Dijker, A.J., \& Koomen, W. (2003). Extending Weiner's attribution-emotion model of stigmatization of ill persons. Basic and Applied Social Psychology, 25(1), 51-68.

Ford, K., Wirawan, D.N., Sumantera, G.M., Sawitri, A.A., \& Stahre, M. (2004). Voluntary HIV testing, disclosure, and stigma among injection drug users in Bali, Indonesia. AIDS Education and Prevention, 16(6), 487-498.

Frye, V., Fortin, P., MacKenzie, S., Purcell, D., Edwards, L.V., Mitchell, S.G., ..., Latka, M.H. (2009). Managing identity impacts associated with disclosure of HIV status: A qualitative investigation. AIDS Care, 21(8), 1071-1078.

Goffman, I. (1963). Stigma: Notes on the management of spoiled identity. Eaglewood Cliffs, NJ: Prentice-Hall.

Gorbach, P.M., Galea, J.T., Amani, B., Shin, A., Celum, C., Kerndt, P., \& Golden, M.R. (2004). Don't ask, don't tell: Patterns of HIV disclosure among HIV positive men who have sex with men with recent STI practising high risk behaviour in Los Angeles and Seattle. Sexually Transmitted Infections, 80(6), 512517.

Greeff, M., Phetlhu, R., Makoae, L.N., Dlamini, P.S., Holzemer, W.L., Naidoo, J.R., ..., Chirwa, M.L. (2008). Disclosure of HIV status: Experiences and perceptions of persons living with HIV/AIDS and nurses involved in their care in Africa. Qualitative Health Research, 18(3), 311-324.

Hancock, B. (1998). Trent focus for research and development in primary health care: An introduction to qualitative research. Nottingham: Trent Focus Group.

Herek, G.M. (1999). AIDS and stigma. American Behavioral Scientist, 42(7), 1106-1116.

Herek, G.M., \& Capitanio, J.P. (1996). 'Some of my best friends': Intergroup contact, concealable stigma, and heterosexuals' attitudes toward gay men and lesbians. Personality and Social Psychology Bulletin, 22(4), $412-424$.

HIV Monitoring Foundation. (2008). Monitoring of human immunodeficiency virus (HIV) infection in the Netherlands. Amsterdam, the Netherlands: HIV Monitoring Foundation.

Holt, R., Court, P., Vedhara, K., Nott, K.H., Holmes, J., \& Snow, M.H. (1998). The role of disclosure in coping with HIV infection. AIDS Care, 10(1), 49-60.

Jones, E., Farina, A., Hastorf, A., Markus, H., Miller, D., \& Scott, R. (1984). Social stigma: The psychology of marked relationships. New York, NY: W.H. Freeman. 
Kalichman, S.C., \& Simbayi, L. (2004). Traditional beliefs about the cause of AIDS and AIDS-related stigma in South Africa. AIDS Care, 16(5), 572-580.

Kumar, A., Waterman, I., Kumari, G., \& Carter, A.O. (2006). Prevalence and correlates of HIV serostatus disclosure: A prospective study among HIV-infected postparturient women in Barbados. AIDS Patient Care and STDs, 20(10), 724-730.

Landau, G., \& York, A.S. (2004). Keeping and disclosing a secret among people with HIV in Israel. Health and Social Work, 29(2), 116-126.

Lee, R.S., Kochman, A., \& Sikkema, K.J. (2002). Internalized stigma among people living with HIV-AIDS. AIDS and Behavior, 6(4), 309-319.

Levy, A., Laska, F., Abelhauser, A., Delfraissy, J.-F., Goujard, C., Boue, F., \& Dormont, J. (1999). Disclosure of HIV seropositivity. Journal of Clinical Psychology, 55(9), 1041-1049.

Melchert, T.P., \& Patterson, M.M. (1999). Duty to warn and intervention with HIV-positive clients. Professional Psychology: Research and Practice, 30(2), 180 186.

Neuberg, S.L., Smith, D.M., Hoffman, J.C., \& Russell, F.J. (1994). When we observe stigmatized and 'normal' individuals interacting: Stigma by association. Personality and Social Psychology Bulletin, 20(2), 196-209.

Nyblade, L., Pande, R., Mathur, S., MacQuarrie, K., \& Kidd, R. (2003). Disentangling HIV and AIDS stigma in Ethiopia, Tanzania and Zambia. Washington, DC: International Center for Research on Women.

Ostrom, R.A., Serovich, J.M., Lim, J.Y., \& Mason, T.L. (2006). The role of stigma in reasons for HIV disclosure and non-disclosure to children. AIDS Care, 18(1), 60-65.

Pachankis, J.E. (2007). The psychological implications of concealing a stigma: A cognitive-affective-behavioral model. Psychological Bulletin, 133(2), 328-345.

Parsons, J.T., VanOra, J., Missildine, W., Purcell, D., \& Gomez, C. (2004). Positive and negative consequences of HIV disclosure among seropositive injection drug users. AIDS Education and Prevention, 16(5), 459-475.

Paxton, S. (2002). The paradox of public HIV disclosure. AIDS Care, 14(4), 559-567.

Petrak, J.A., Doyle, A.M., Smith, A., Skinner, C., \& Hedge, B. (2001). Factors associated with self-disclosure of HIV serostatus to significant others. British Journal of Health Psychology, 6(Pt. 1), 69-79.

Riggs, S.A., Vosvick, M., \& Stallings, S. (2007). Attachment style, stigma and psychological distress among $\mathrm{HIV}+$ adults. Journal of Health Psychology, 12(6), 922-936.

Sachperoglou, E., \& Bor, R. (2001). Disclosure of HIV seropositivity and social support: General patterns in Greece. European Journal of Psychotherapy, Counselling and Health, 4(1), 103-122.

Schrimshaw, E.W., \& Siegel, K. (2003). Perceived barriers to social support from family and friends among older adults with HIV/AIDS. Journal of Health Psychology, $8(6), 738-752$.

Serovich, J.M. (2001). A test of two HIV disclosure theories. AIDS Education and Prevention, 13(4), 355364.

Serovich, J.M., \& Mosack, K.E. (2003). Reasons for HIV disclosure or nondisclosure to casual sexual partners. AIDS Education and Prevention, 15(1), 70-80.

Siegel, K., Lekas, H.-M., \& Schrimshaw, E.W. (2005). Serostatus disclosure to sexual partners by HIVinfected women before and after the advent of HAART. Women \& Health, 41(4), 63-85.

Simoni, J.M., Mason, H.R.C., Marks, G., Ruiz, M.S., Reed, D., \& Richardson, J.L. (1995). Women's selfdisclosure of HIV infection: Rates, reasons, and reactions. Journal of Consulting and Clinical Psychology, 63(3), 474-478.

Smart, L., \& Wegner, D.M. (1999). Covering up what can't be seen: Concealable stigma and mental control. Journal of Personality and Social Psychology, 77(3), 474-486.

Smith, R., Rossetto, K., \& Peterson, B.L. (2008). A meta-analysis of disclosure of one's HIV-positive status, stigma and social support. AIDS Care, 20(10), 1266-1275.

Sowell, R.L., Seals, B.F., Phillips, K.D., \& Julious, C.H. (2003). Disclosure of HIV infection: How do women decide to tell? Health Education Research, 18(1), 32-44.

Steward, W.T., Herek, G.M., Ramakrishna, J., Bharat, S., Chandy, S., Wrubel, J., \& Ekstrand, M.L. (2008). HIV-related stigma: Adapting a theoretical framework for use in India. Social Science and Medicine, 67(8), $1225-1235$.

Stutterheim, S.E., Pryor, J.B., Bos, A.E., Hoogendijk, R., Muris, P., \& Schaalma, H.P. (2009). HIV-related stigma and psychological distress: The harmful effects of specific stigma manifestations in various social settings. AIDS, 23(17), 2353-2357.

Valle, M., \& Levy, J. (2009). Weighing the consequences: Self-disclosure of HIV-positive status among African American injection drug users. Health Education \& Behavior, 36(1), 155-166.

Vallerand, A.H., Hough, E., Pittiglio, L., \& Marvicsin, D. (2005). The process of disclosing HIV serostatus between HIV-positive mothers and their HIV-negative children. AIDS Patient Care and STDs, 19(2), 100-109.

Vanable, P.A., Carey, M.P., Blair, D.C., \& Littlewood, R.A. (2006). Impact of HIV-related stigma on health behaviors and psychological adjustment among HIVpositive men and women. AIDS and Behavior, 10(5), 473-482.

Visser, M.J., Neufeld, S., de Villiers, A., Forsyth, B.W.C., \& Makin, J.D. (2008). To tell or not to tell: South African women's disclosure of HIV status during pregnancy. AIDS Care, 20(9), 1138-1145. 
Waugh, S. (2003). Parental views on disclosure of diagnosis to their HIV-positive children. AIDS Care, 15(2), 169-176.

Yoshioka, M.R., \& Schustack, A. (2001). Disclosure of HIV status: Cultural issues of Asian patients. AIDS Patient Care and STDs, 15(2), 77-82.
Zea, M.C., Reisen, C.A., Poppen, P.J., Bianchi, F.T., \& Echeverry, J.J. (2005). Disclosure of HIV status and psychological well-being among Latino gay and bisexual men. AIDS and Behavior, 9(1), 15-26. 